Anna Gagat-Matuła, PhD, https://orcid.org/0000-0002-9349-5924

Institute of Special Needs Education

Pedagogical University of Krakow

\title{
Marital communication and coping with stress among parents of children with ASD during the SARS CoV 2 pandemic
}

\section{Komunikacja małżeńska a radzenie sobie ze stresem rodziców dziecka z ASD w okresie pandemii SARS CoV 2}

https://doi.org/10.34766/fetr.v47i3.810

\begin{abstract}
The article presents the correlation between marital communication and the coping styles of parents of a child with ASD during the SARS CoV-2 pandemic. The study involved 46 married mothers and 34 married fathers raising children with autism spectrum disorders. The following tools were used: The Marital Communication Questionnaire (KKM) by M. Plopa and M. Kazmierczak and the Polish version of the CISS Coping Questionnaire by Endler and Park. The results of the research showed that respondents more often prefer constructive coping with stress using the task focused style (SSZ) if a spouse assesses both themselves and their spouse as more supportive and engaged in communication and less depreciation. The respondents more often prefer non-constructive coping with stress using and the emotion-focused style (SSE) or the avoidance-focused style (SSU), if the spouse assesses both themselves and their spouse as depressed. The greater the difference between their own assessment and the assessment of their spouse in supportive communication, the more often the respondents prefer the style focused on emotions (SSE) and the style focused on avoidance (SSU). Moreover, the greater the difference between self-assessment and that of the spouse in depreciation communication, the less often the task-focused style (SSZ) was preferred. The results are statistically significant.
\end{abstract}

Keywords: communication, marriage, stress management, autism spectrum disorders, SARS-CoV-2 pandemic

Abstrakt: Przedmiotem badań prezentowanych $\mathrm{w}$ artykule będą związki między komunikacją małżeńską a stylami radzenia sobie ze stresem rodziców dziecka z ASD w okresie pandemii SARS CoV-2. W badaniu wzięło udział 46 matek i 34 ojców wychowujących dziecko z zaburzeniami spektrum autyzmu, pozostających w związkach małżeńskich. W badaniach wykorzystano następujące narzędzia: Kwestionariusz Komunikacji Małżeńskiej (KKM) autorstwa M. Plopy i M. Kaźmierczaka i polską wersję Kwestionariusza Radzenia Sobie w Sytuacjach Stresowych CISS autorstwa Endlera i Parkera.Wyniki badań wskazują, że badani częściej preferują konstruktywne radzenie sobie ze stresem: styl skoncentrowanym na zadaniu (SSZ), jeśli małżonek ocenia zarówno siebie jak i swojego współmałżonka jako bardziej wspierającego $\mathrm{i}$ zaangażowanego $\mathrm{w}$ komunikację a mniej deprecjonującego. Badani częściej preferują niekonstruktywne radzenie sobie ze stresem: styl skoncentrowany na emocjach (SSE) i styl skoncentrowany na unikaniu (SSU), jeśli małżonek ocenia zarówno siebie jak i współmałżonka jako deprecjonującego. Im większa jest różnica pomiędzy własną oceną i oceną współmałżonka w komunikacji wspierającej tym częściej badani preferują styl skoncentrowany na emocjach (SSE) i styl skoncentrowany na unikaniu (SSU) . Ponadto im większa jest różnica pomiędzy oceną własną i oceną współmałżonka w komunikacji deprecjonującej tym rzadziej preferowany był styl skoncentrowanym na zadaniu (SSZ). Wyniki są istotne statystycznie.

Słowa klucze: komunikacja, małżeństwo, radzenie sobie ze stresem, spektrum zaburzeń autystycznych, pandemia SARS-CoV-2 


\section{Introduction}

In late December 2019, a new strain of the SARS-CoV-2 coronavirus was detected in the city of Wuhan, Hubei Province, in the People's Republic of China. On January 30, 2020, the World Health Organization (WHO) declared the outbreak a public health emergency of international concern, and on February 11, 2020, the International Committee on Taxonomy of Viruses (ICTV) decided to name the 2nd severe acute failure syndrome coronavirus (SARS-CoV-2), and the WHO finally decided to name the disease caused by this virus as COVID-19 (a coronavirus disease identified in 2019). Following large epidemics of this disease in many countries, in which thousands of people died, on March 11, 2020, the WHO declared a pandemic (International Pharmaceutical Federation, 2020).

The detected virus started a period of many social changes related to restrictions and limitations in the spheres of daily life and the economy. During a pandemic, a much larger part of society spends more time in isolation, and therefore communication problems in the family may arise due to stress related to the possibility of falling ill and limited social contacts, as well as the feeling of being burdened with work duties and the completion of educational obligations by children at home, often in a small space. Research results show that in parents of children under the age of 18 , the epidemic and its personal, social and economic consequences may lead to an increase in stress that is beyond the individual's ability to adapt and cope, leading to the development of depression and anxiety symptoms with significant clinical severity. During the epidemic, many of such parents struggled to reconcile work, home and parental responsibilities. The feeling of being threatened with the negative consequences of COVID-19 on the health and life of oneself and loved ones may have a greater impact on the severity of depression and anxiety symptoms in parents, as they may fear that they will not be able to care for their child or children if they fall ill. In addition, parents who are more concerned about the consequences of COVID-19 may isolate themselves more from social contacts with others (friends, family) and, as a result, feel the effects of the epidemic more acutely (Gambin et al., 2020).

The pandemic may particularly affect relationships in families raising a child with autism spectrum disorder (ASD). Their economic, social and psychological situation was already difficult even before the outbreak of the pandemic, and as a result of the situation may worsen further (Gagat-Matuła, 2021, a, Manning et al., 2021). Moreover, families with children on the spectrum reported greater behavioral problems during the lockdown and more parental distress (Lavante et al., 2021). The pandemic has for many families with children with ASD increased the difficulties in managing daily activities, especially leisure and organized activities, and has exacerbated behavioral problems (Colizzi et al., 2020). Research shows that during the pandemic, both parents of children with ASD and children with ASD had a significantly higher level of anxiety than parents of healthy children and 
healthy children (Amorim et al., 2020). Moreover, parents of children with ASD were more likely to suffer from depression in the lockdown period than parents of healthy children (Wang et al, 2021).

Gagat-Matuła's (2021 a) research shows that children with ASD cannot cope with emotions during the SARS CoV-2 pandemic, and that their families need support. This is also influenced by the uncertain economic situation of the family. The analysis of data on the experienced emotions and mood of children with ASD from families with low and medium financial status during the SARS-CoV-2 pandemic showed statistically significant differences in the groups on the scales of fear, sadness and negative mood. The results indicate that children with ASD from families with low financial status experience higher levels of fear and sadness than children with ASD from families with average financial status. Moreover, children with ASD from poor families have a more negative mood than children with ASD from families with an average financial status. Other studies also show that mothers of children with ASD cannot cope with stress and need social support (Gagat-Matuła, 2021, b).

Research before the outbreak of the pandemic by Dąbrowska and Pisula (2010), Bitsika, Sharpley and Bell (2013), Sekułowicz (2013), Shobana and Saravanan, (2014), Bonis, (2016), Hartley et al., (2016), Padden and James (2017), Pisula and Porębowicz-Dörsmann (2017) shows that parents with a child with autism spectrum disorders are in a particularly difficult situation. The level of parental stress experienced is higher in mothers than in fathers, and, importantly, is more acute not only in comparison with parents of children with normal development, but also in comparison with parents of children with other developmental disorders. Research by Greszt et al., (2020) shows that the strong stress experienced by parents of children with ASD can lead to serious consequences in the form of parents experiencing energy burnout.

In the literature on the subject, there are few studies that directly consider marital relationships and marital communication among parents of children with autism spectrum disorders, and the results of any such studies are inconclusive. The experiences related to the diagnosis and rehabilitation of a child affect mutual relations. Additionally, a relationship crisis can aggravate fatigue and physical exhaustion for the woman, who is usually overinvolved in caring for the child (Randall, Parker, 2010). This is also confirmed by the research of Gerstein et al. (2009), as well as that of Zdanowicz and Zasępa (2017), which indicates that the quality of the marital relationship and relationship satisfaction among these parents is lower compared to the parents of children with other types of developmental disorders or the parents of normal children (Hartley et al., 2010; Gosztyła, 2015). Research also shows that parenting a child with autism spectrum disorder (ASD) is associated with increased marital conflicts and reduced marital love (Chan, Leung, 2020).

Other studies, including by Altiere and Von Kluge (2009), Myers et al. (2009) and Hock et al., (2012) contradict the previous research and indicate that the high quality of the 
marital relationship of parents of children with autism spectrum disorders does not differ from that of parents who have a healthy child.

A pandemic may be a stress factor as it brings with it certain consequences, such as fear for life and health, isolation, risk of losing income, and problems with access to health care, including rehabilitation. All this forces parents to develop new coping strategies and seek external family support.

In clinical psychology, the role of stress is emphasized as a factor that worsens the efficiency and effectiveness of functioning in various spheres of human life. Stress is reduced by effective coping, while its accumulation is the result of coping considered ineffective. According to R. Lazarus and S. Folkman (1984), stress is defined as "... a specific reaction between a person and the environment, which is assessed by this individual as burdening their resources and jeopardizing their well-being" (p. 19). The process of coping with stress covers the entirety of an individual's efforts to deal with a given situation. Hence, many authors consider "coping" in terms of a general disposition, or coping style. This is how it is presented by Endler and Parker, who proposed three styles. Two of these correspond to the coping functions mentioned by R. Lazarus and S. Folkman, i.e. task-focused and emotionalfocused. The third style is avoidance coping, which aims to reduce the effects of the stressor.

The task-focused style involves taking action to solve a problem or change an existing stressful situation by using cognitive processes.

The style focused on emotions is characteristic of people who prefer wishful thinking and fantasizing at the expense of effective and rational action aimed at removing or minimizing the stress stimulus.

Avoidance-focused style consists of rejecting thoughts about the fundamental problem, and not allowing people to relieve it or become involved in solving the stressful situation; a person "escapes" from the problem by performing substitute activities (e.g. shopping) (Strelau et al., 2005).

In the process of coping with stress, the support offered by those closest to you, including in particular that offered by the spouse, is of great importance and is the most effective form of social support (Argyle, 1991; Ekas et al., 2015). Research shows that high quality of conjugal relationship between parents of children with autism belongs to key resources enabling smoothing out the impact of stress and lowering the number of depression indicators (Benson, Kersh, 2011; Broberg, 2013; Kersh et al, 2006; Norlin, Goetz et al., 2016 Solomon, Chung, 2012). Moreover, the results of the research show that a strong bond between spouses may provide a buffer against the influence of stressful factors related to caring for a child with autism. The research shows that cooperation may become the most important factor in the marriage bond, reducing the sources of stress and reducing its level (Greszta et al., 2020). Marital satisfaction, especially in the case of fathers, reduces the perceived effects of parental stress (Brown, 2019). 
Proper communication in marriage is a prerequisite for the development of the marriage bond, and this is essential to the quality of the marriage relationship. Proper communication leads to the deepening of the sense of belonging in the marriage M. Ryś (1999). According to M. Plopa, communication in marriage consists of the following elements: providing support to the spouse, the degree of involvement in the communication process and any aggressive action directed against the spouse affecting the functioning of the married couple (Kaźmierczak, Plopa, 2008).

These dimensions are named accordingly:

- support is understood as showing respect to the partner by appreciating their efforts, showing interest in the partner's needs and problems, as well as active participation in the process of jointly solving these problems. Therefore, care for the partner is manifested not only in difficult moments, but also in various everyday situations

- commitment refers to the ability to create an atmosphere of mutual understanding and closeness in a relationship by showing feelings for each other, emphasizing the uniqueness and importance of a partner for us, diversifying the routine of everyday life and preventing conflicts in the relationship

- depreciation is defined as showing aggression towards the partner, the desire to dominate the partner and control their actions, and the lack of respect for the dignity of the partner (Kaźmierczak, Plopa, 2008). The family is a dynamic network of mutual relations based on one's own values and a system of communication. All this determines behavior within a family and transformations resulting from the reaction to difficult situations, such as the current SARS Co-V 2 pandemic. The studies confirm the thesis that the bond between spouses in every family is essential as this element integrates the family, but that in families with a sick child this is especially important (Greszta et al, 2020).

As the family system reacts to the emergence of a disability, family members are accompanied by permanent fear, uncertainty and anger, but also hope, love and mutual support, which are a predictor of coping with difficult situations. Communication in marriage and a high level of support and commitment make it possible to constructively solve difficult problems and resolve differences of opinion in the family.

\section{Assumptions of own research}

The aim of the research was an attempt to determine the correlation between marital communication and the styles of coping with stress among parents of a child with ASD during the SARS CoV-2 pandemic.

It was decided to verify if and how the types of communication between spouses, that is supportive, committed or depreciation communication by the spouses, influence their styles of coping with stress during the SARS CoV-2 pandemic in the following dimensions: 
task-focused style (SSZ), emotion-focused style (SSE) and avoidance-focused style (SSU), which can take two forms: engaging in substitute activities (ACZ) or seeking social contacts (PKT).

The following research hypotheses were formulated: H1 There is a relationship between high scores for self-support and committed communication and the task-focused style (SSZ) in difficult situations.

$\mathrm{H} 2$ There is a relationship between high scores for self- depreciation communication and the Emotion-Focused Style (SSE) and the Avoidance-Focused Style (SSU), which can take two forms: engaging in substitute activities (ACZ) or seeking social contacts (PKT).

H3 There is a correlation between the perception of a spouse as supportive and involved in communication and the task-focused style (SSZ) in difficult situations.

H4 There is a correlation between the perception of a spouse as depreciation and the emotion-focused style (SSE) and avoidance-focused style (SSU), which can take two forms: engaging in substitute activities (ACZ) or seeking social contacts (PKT).

H5 The greater the difference between the assessment of oneself and of one's spouse as either supportive, committed or depreciation, the more often the respondents prefer the style focused on emotions (SSE) and the style focused on avoidance (SSU), which can take two forms: engaging in substitute activities ( ACZ) or searching for social contacts (PKT).

\section{Test method and sample characteristics}

The diagnostic survey method was employed in the research study and the following tools were used: The Marital Communication Questionnaire (KKM) by M. Plopa and M. Kaźmierczak, and the Polish version of the CISS Coping Questionnaire by Endler and Parker.

The Marriage Communication Questionnaire (KKM) by M. Kaźmierczak and M. Plopa. This questionnaire comes in two versions and is designed to study communication behavior in married couples. In the first version, each of the married partners assesses their own communication behavior, and in the second that of their partner. Each version consists of 30 items examining the three main dimensions of communication in marriage: support (10 items), commitment (9 items) and depreciation (11 items). These dimensions are described in the theoretical introduction on communication behavior. The reliability scores of the individual dimensions of the Marriage Communication Questionnaire are, respectively: Cronbach's $\alpha=0.91$ for the support dimension in the assessment of one's own behavior and $\alpha=0.93$ in the assessment of the partner's behavior; Cronbach's $\alpha=0.85$ for the commitment dimension in the assessment of one's own behavior and $\alpha=0.77$ in the assessment of the partner's behavior; and Cronbach's $a=0.87$ for the depreciation dimension in the assessment 
of one's own behavior and $a=0.91$ in the assessment of the partner's behavior (Kaźmierczak, Plopa, 2008).

The CISS Coping Questionnaire for Stressful Situations by Endler and Parker. The questionnaire consists of 48 simple statements about the different behaviors people undertake in stressful situations. Respondents are required to respond to each statement by circling a number (from 1 to 5 ) that best defines the frequency of the activity undertaken. The authors created three scales that define the styles of coping with stress: the task-focused style (SSZ), the emotion-focused style (SSE) and the avoidance-focused style (SSU), which can take two forms: engaging in substitute activities (ACZ). ) or searching for social contacts (PKT). As the main scales consist of 16 items, respondents can score between 16 and 80 points in each. However, on the ACZ subscale, consisting of 8 items, respondents can obtain between 8 and 40 points, and on the PKT subscale (5 items) between 5 and 25 points. After calculating the raw results, these should be referred to the sten norms, which were developed separately for different age groups: 16-24 years, 25-54 years and 55-79 years. The psychometric properties of the scales in the Polish version of the questionnaire were shown to be satisfactory for both stability and reliability indicators (Strelau et al., 2005). The research was conducted in 2021 at the Specialist Outpatient Clinic for People with Autism for Children in Leżajsk. Deliberate random sampling was used. The study involved 46 married mothers and 34 married fathers raising children with autism spectrum disorders.

\section{Results}

Appropriate statistical procedures were used to verify the research hypotheses. In order to verify hypothesis 1 and hypothesis 2, analyses of the r-Pearson correlation (regarding the interval level of the variables, the variables had distributions close to the normal distribution) were carried out between the assessment of marital communication and the coping styles of parents of a child with ASD during the pandemic SARS CoV-2. The obtained correlation coefficients from the conducted analyses are presented in Table 1.

Table 1. Pearson's r correlation coefficients between self-assessment of communication dimensions in a marriage relationship and styles of coping with stress.

\begin{tabular}{|l|c|c|c|}
\hline $\begin{array}{c}\text { KKM } \\
\text { CISS }\end{array}$ & $\begin{array}{c}\text { Supportive } \\
\text { communication }\end{array}$ & $\begin{array}{c}\text { Committed } \\
\text { communication }\end{array}$ & $\begin{array}{c}\text { Depreciation } \\
\text { Communication }\end{array}$ \\
\hline Task-oriented coping (SSZ) & $0,60^{*}$ & $0,53^{*}$ & $-0,55^{*}$ \\
\hline Emotion-oriented coping (SSE) & $-0,55^{*}$ & $-0,44^{*}$ & $0,61^{*}$ \\
\hline Avoidance-oriented coping (SSU) & $-0,49^{*}$ & $-0,47^{*}$ & $0,59^{*}$ \\
\hline Engaging in substitute activities (ACZ) & $-0,46^{*}$ & $-0,38^{*}$ & $0,53^{*}$ \\
\hline Seeking social contacts (PKT) & $-0,44^{*}$ & $-0,39^{*}$ & $0,55^{*}$ \\
\hline
\end{tabular}

$* \mathrm{p}<.05$

Source: own study. 
The analysis of the r-Pearson correlation between the assessment of communication in marriage and the styles of coping with stress in difficult situations confirmed hypothesis 1 that there is a correlation between high scores for self-supporting and engaged communication and the preferred task-focused style (SSZ) in difficult situations, as well as hypothesis 2 that there is a relationship between high scores for self- depreciation communication and the emotion-focused style (SSE) and the avoidance-focused style (SSU), which may take two forms: engaging in substitute activities (ACZ) or seeking social contacts (PKT). The results of the research indicate that there is a statistically significant correlation between the dimensions of communication and the styles of coping with stress in difficult situations. Statistical analyses showed that:

- The higher the respondents assessed themselves as more supportive and involved in marital communication, the more often in difficult situations they chose stress-coping strategies that are constructively focused on the task (SSZ). Positive significant correlations with moderate relationship strength were observed.

- The higher the respondents assessed themselves as more supportive and involved in marital communication, the less often they chose non-constructive coping with difficult situations, preferring the style focused on emotions (SSE) and the style focused on avoidance (SSU), which can take two forms: engaging in substitute activities (ACZ) or searching for social contacts (PKT). Negative significant correlations with low or moderate relationship strength were observed.

- The more respondents perceived themselves as depreciation people in communication, the more often they chose non-constructive coping with difficult situations, preferring the style focused on emotions (SSE) and the style focused on avoidance (SSU), which can take two forms: engaging in substitute activities (ACZ) or searching for social contacts (PKT). Positive significant correlations with moderate relationship strength were observed.

- The more respondents perceived themselves as depreciation people in communication, the less often they chose in difficult situations they chose stress-coping strategies that are constructively focused on the task (SSZ). Negative significant correlations with moderate relationship strength were observed.

The research also assumed that there is a relationship between high assessment of respondents' spouses in the communication process as supportive and engaged, and the task-focused style (SSZ) preferred by the respondents in difficult situations, and that there is a relationship between high results for depreciation communication using the spouse's style focused on emotions (SSE) and the style focused on avoidance (SSU), which may take two forms: engaging in alternative activities (ACZ) or seeking social contacts (PKT), which was the content of hypotheses 3 and 4 . 
Following this, in order to verify hypotheses 3 and 4, analyses of the $r$ - Pearson correlation (regarding the interval level of the variables, the variables had distributions close to the normal distribution) were performed between the assessment of the spouse's communication in marriage and the styles of coping with stress. The correlation coefficients obtained from the conducted analyses are presented in Table 2.

Table 2. Pearson's r correlation coefficients between the spouse's assessment of the dimensions of communication in a marriage relationship and the styles of coping with stress.

\begin{tabular}{|l|c|c|c|}
\hline CISS & $\begin{array}{c}\text { Supportive } \\
\text { communication }\end{array}$ & $\begin{array}{c}\text { Committed } \\
\text { communication }\end{array}$ & $\begin{array}{c}\text { Depreciation } \\
\text { communication }\end{array}$ \\
\hline Task-oriented coping (SSZ) & $0,63^{*}$ & $0,56^{*}$ & $-0,49^{*}$ \\
\hline Emotion-oriented coping (SSE) & $-0,58^{*}$ & $-0,46^{*}$ & $0,51^{*}$ \\
\hline Avoidance-oriented coping (SSU) & $-0,41^{*}$ & $-0,44^{*}$ & $0,50^{*}$ \\
\hline Engaging in substitute activities (ACZ) & $-0,39^{*}$ & $-0,37^{*}$ & $0,49^{*}$ \\
\hline Seeking social contacts (PKT) & $-0,38^{*}$ & $-0,38^{*}$ & $0,34^{*}$ \\
\hline
\end{tabular}

${ }^{*} \mathrm{p}<.05$

Source: own study.

The analysis of the r-Pearson correlation between the assessment of the spouse's communication and the preferred styles of coping with difficult situations, confirmed hypothesis 3 that there is a correlation between high scores of a spouse in supportive and engaged communication and the task-focused style (SSZ) preferred by the respondents, as well as hypothesis 4 , that there is a relationship between high results in depreciation spouse communication and respondents preference for the emotion-focused style (SSE) and avoidance-focused style (SSU), which can take two forms: engaging in alternative activities (ACZ) or seeking social contacts (PKT). The results of the research indicate that there is a statistically significant correlation between the spouse's assessments in particular dimensions of communication and the preferred styles of coping with difficult situations.

Statistical analyses showed that:

- The higher the respondents assessed their spouses as supportive and involved in communication, the more often they preferred constructive coping with difficult situations: the task-focused style (SSZ). Positive significant correlations with moderate relationship strength were observed.

- The higher the respondents assessed their spouses as supportive and involved in marital communication, the less often they chose non-constructive coping with difficult situations, preferring the style focused on emotions (SSE) and the style focused on avoidance (SSU), which can take two forms: engaging in substitute activities (ACZ) or searching for 
social contacts (PKT). Negative significant correlations with low or moderate relationship strength were observed.

- The more respondents perceived their spouse as a person depreciation in communication, the more often they adopted in difficult situations an emotional-focused style (SSE) and an avoidance-focused style (SSU), which can take two forms: engaging in alternative activities (ACZ) or seeking social contacts (PKT). Positive significant correlations with low or moderate relationship strength were observed.

- The more respondents perceived their spouse as a person depreciation in communication, the less often they chose in difficult situations they chose stress-coping strategies that are constructively focused on the task (SSZ). Negative significant correlations with moderate relationship strength were observed.

It was assumed in the research that there is a correlation between the differences in the assessment of one's own communication with a spouse and the spouse's communication as supportive, committed and depreciation, and the styles of coping with difficult situations preferred by the respondents, which was consistent with the content of hypothesis 5 .

Subsequently, in order to verify hypothesis 5, analyses of the r-Pearson correlation (regarding the interval level of the variables, the variables had distributions close to the normal distribution) were carried out between the significant difference in assessing oneself and a spouse as supportive, committed and deprecating, and the preferred non-constructive coping styles: the emotion-focused style (SSE) and the avoidance-focused style (SSU), which can take two forms: engaging in substitute activities (ACZ) or seeking social contacts (PKT).

The obtained correlation coefficients from the conducted analyses are presented in Table 3.

Table 3. Pearson's $r$ correlation coefficients between own and spouse's assessment of the dimensions of relationship communication and the styles of coping with difficult situations preferred by the respondents.

\begin{tabular}{|l|c|c|c|}
\hline CISS & $\begin{array}{c}\text { Supportive } \\
\text { communication }\end{array}$ & $\begin{array}{c}\text { Committed } \\
\text { communication }\end{array}$ & $\begin{array}{c}\text { Depreciation } \\
\text { communication }\end{array}$ \\
\hline Task-oriented coping (SSZ) & $-0,29$ & $-0,27$ & $-0,41^{*}$ \\
\hline Emotion-oriented coping (SSE) & $0,39^{*}$ & 0,23 & 0,26 \\
\hline Avoidance-oriented coping (SSU) & $0,34^{*}$ & 0,29 & 0,23 \\
\hline Engaging in substitute activities (ACZ) & $0,31^{*}$ & 0,23 & 0,19 \\
\hline Seeking social contacts (PKT) & $0,32^{*}$ & 0,19 & 0,21 \\
\hline
\end{tabular}

${ }^{*} \mathrm{p}<.05$

Source: own study. 
The results of the research confirm hypothesis 5, indicating that the greater the difference between self-assessment and the assessment of a spouse in supportive communication, the more often the respondents prefer the style focused on emotions (SSE) and the style focused on avoidance (SSU), which can take two forms: engaging in alternative activities (ACZ) or seeking social contacts (PKT), and also that the greater the difference between self-assessment and the assessment of a spouse in depreciation communication, the less often the task-focused style (SSZ) was preferred. However, the relationship between the difference in the assessment of oneself and a spouse as committed and the task-focused style (SSZ) turned out not to be statistically significant.

\section{Summary}

The aim of the research was an attempt to determine the correlation between marital communication and the styles of coping with stress among parents of a child with ASD during the SARS CoV-2 pandemic.

The results of the research showed that respondents more often prefer constructive coping with stress using the task focused style (SSZ) if a spouse assesses both themselves and their spouse as more supportive and engaged in communication and less depreciation. Thus, if a spouse finds both themselves and their spouse less supportive and committed and more depreciation, respondents more often prefer non-constructive coping with stress using the emotion-focused style (SSE) and the avoidance-focused style (SSU), which can take two forms: engaging in alternative activities (ACZ) or seeking social contacts (PKT), The research has shown that the greater the difference between self-assessment and the assessment of the spouse in supportive communication, the more often the respondents prefer the emotionfocused style (SSE) and the avoidance-focused style (SSU), which can take two forms: engaging in substitute activities (ACZ) or looking for social contacts (PKT), and also that the greater the difference between self-assessment and the assessment of the spouse in depreciation communication, the less often the task-focused style (SSZ) was preferred. However, the relationship between the difference in the assessment of oneself and one's spouse as committed and the task-focused style (SSZ) was shown not to be statistically significant.

\section{Bibliography:}

Altiere, M.J., Von Kluge, S. (2009). Searching for acceptance: challenges encountered while raising a child with autism, Journal of Intellectual and Developmental Disability, 34, 142152, https://doi.org/10.1080/13668250902845202. 
Amorim, R., Catarino, S., Miragaia, P., Ferreras, C., Viana, V., Guardiano, M. (2020). The impact of COVID-19 on children with autism spectrum disorder, Revista de Neurologia, 71 (8), 285-291, https:/ / doi.org/10.33588/rn.7108.2020381.

Argyle, M. (1999). Psychologia stosunków międzyludzkich, Warszawa: PWN.

Benson, P.R., Kersh, J. (2011). Marital Quality and Psychological Adjustment Among Mothers of Children with ASD: Cross-Sectional and Longitudinal Relationships, Journal of Autism \& Developmental Disorders, 41, 1675-1685, https://doi.org /10.1007/s10803-011-1198-9.

Bitsika, V., Sharpley, C., Bell, R. (2013). The buffering effect of resilience upon stress, anxiety and depression in parents of a child with an autism spectrum disorder, Journal of Developmental and Physical Disabilities, 25 (5), 533-543, https://doi.org/10.1007/s10882-013-9333-5.

Bonis, S. (2016), Stress and Parents of Children with Autism: A Review of Literature, Issues Ment Health Nurs, 37 (3), 153-63, https:/ / doi.org/10.3109/01612840.2015.1116030.

Brown, M., Whiting, J., Kahumoku, Fessler, E., Witting, A.B., Jensen, J. (2019). A Dyadic Model of Stress, Coping, and Marital Satisfaction Among Parents of Children With Autism, Family Relations, 69 (1), 138-150, https:/ / doi.org/10.1111/fare.12375.

Chan, K.K.S., Leung, D.C.K. (2020). The Impact of Child Autistic Symptoms on Parental Marital Relationship: Parenting and Coparenting Processes as Mediating Mechanisms, Autism Research Journal, 13 (9), 1516-1526, https://doi.org /10.1002/aur.2297.

Colizzi, M., Sironi, E., Antonini, F., Ciceri, M.L., Bovo, C., Zoccante, L. (2020). Psychosocial and Behavioral Impact of COVID-19 in Autism Spectrum Disorder: An Online Parent Survey, Brain Sciences, 10, 341, https:/ / doi.org/10.3390/brainsci10060341.

Dąbrowska, A., Pisula, E. (2010). Parenting stress and coping styles in mothers and fathers of pre-school children with autism and Down syndrome, Journal of Intellectual Disability Research, 54, 266-280, https:// doi.org/10.1111/j.1365-2788.2010.01258.x.

Ekas, N.V., Timmons, L., Pruitt, M., Ghilain, C., Alessandri, M. (2015). The Power of Positivity: Predictors of Relationship Satisfaction for Parents of Children with Autism Spectrum Disorder, Journal of Autism \& Developmental Disorders, 45, 1997-2007, https://doi.org/10.1007/s10803-015-2362-4.

Gerstein, E.D., Crnic, K.A., Blacher, J., Baker, B.L. (2009). Resilience and the course of daily parenting stress in families of young children with intellectual disabilities, Journal of Intellectual Disability Research, 53, 981-997, https://doi.org/10.1111/j.13652788.2009.01220.x.

Goetz, G.L., Hickey, E.J., Hartley, S.L. (2016). New directions in family research: Marital quality in parents of children with ASD. Spotlight on Disability, 
http://www.apa.org/pi/disability/resources/publications/newsletter/2016/09/pa rents-children-autism.

Gosztyła, T. (2015). Marriage Satisfaction of Parents of Children with Autism. Introductory Exploration of the Problem among Polish Married Couples Rearing Children with Autism, Kwartalnik Naukowy Fides et Ratio, 4 (24), 228-247, https:// doi.org/10.5604/01.3001.0010.0975.

Greszta, E., Ryś, M., Trębicka, P., Hoffer-Buczkowska, L. (2020). Poczucie więzi ze współmałżonkiem a poziom stresu i wypalenie się sił psychicznych u rodziców dzieci z autyzmem, Kwartalnik Naukowy Fides Et Ratio, 41 (1), 340-358, https://doi.org/10.34766/fetr.v41i1.239.

Hartley, S.L., Barker, E.T., Seltzer, M.M., Greenberg, J., Bolt, D., Floyd, F., Orsmond, G. (2010). The Relative Risk and Timing of Divorce in Families of Children With an Autism Spectrum Disorder, Journal of Family Psychology, 24, 449-457, https:/ / doi.org/ 10.1037/a0019847.

Hartley, S.L., Papp, L.M., Blumenstock, S.M., Floyd, F., \& Goetz, G.L. (2016). The effect of daily challenges in children with autism on parents' couple problem-solving interactions, Journal of Family Psychology, 30 (6), 732-742, https://doi.org/10.1037/fam0000219.

Hock, R.M., Tamm, T.M., Ramiach, J.L. (2012). Parenting children with autism spectrum disorders: a crucible for coupe relationships, Child and Family Social Work, 17, 406415, https:/ / doi.org/10.24917/20845596.10.10.

Kaźmierczak, M., Plopa M. (2008). Kwestionariusz Komunikacji Małżeńskiej, Warszawa: Wydawnictwo VIZJA PRESS \& IT.

Kersh, J., Hedvat, T.T., Hauser-Cram, P., Warfield, M.E. (2006). The contribution of marital quality to the well-being of parents of children with developmental disabilities, Journal of Intellectual Disability Research, 50, 883-893, https://doi.org/10.1111/j.13652788.2006.00906.x.

Levante, A., Petrocchi, S., Bianco, F., Castelli, I., Colombi, C., Keller, R., Narzisi, A., Masi, G., Lecciso, F. (2021). Psychological Impact of COVID-19 Outbreak on Families of Children with Autism Spectrum Disorder and Typically Developing Peers: An Online Survey. Brain Science.11(6), 808, https:/ / doi.org/10.3390/brainsci11060808.

Lazarus, R., Folkman S. (1984). Stress appraisal and coping, New York: Springer Publishing Company.

Manning, J., Billian, J., Matson, J., Allen C., Soares N. (2021). Perceptions of Families of Individuals with Autism Spectrum Disorder during the COVID-19 Crisis, Journal of Autism and Developmental Disorders, 51, 2920-2928, https://doi.org/10.1007/s10803020-04760-5. 
Myers, B.J., Macintosh, V.H., Goin-Kochel, R.P. (2009). My greatest joy and my greatest hartache': Parents' own words on how having child in the autism spectrum Has affected their lives and their families lives, Research in Autism Spectrum Disorders, 3, 670-684, https:/ / doi.org/10.1016/J.RASD.2009.01.004.

Norlin, D., Broberg, M. (2013). Parents of children with andwithout intellectual disability: Couple relationship andindividual well-being, Journal of Intellectual Disability Research, 57, 552-566, https://doi.org/10.1111/j.1365-2788.2012.01564.x.

Padden, C., James, J.E. (2017). Stress among parents of children with and without autism spectrum disorders: a comparison involving physiological indicators and parent selfreports, Journal of Developmental and Physical Disabilities, 29, 567-586, https:// doi.org/10.1007/s10882-017-9547-z.

Pisula, E., Porębowicz-Dörsmann, A. (2017). Family functioning, parenting stress and quality of life in mothers and fathers of Polish children with high functioning autism or Asperger syndrome, PLoS One, 16, 12 (10), https://doi.org/10.1371/journal.pone.0186536.

Randall, P., Parker, J. (2010). Autyzm. Jak pomóc rodzinie, Gdańsk: Wydawnictwo GWP.

Ryś, M., (1999). Psychologia matżeństwa w zarysie, Warszawa: Centrum Metodyczne Pomocy Psychologiczno-Pedagogicznej MEN.

Solomon, A.H. Chung, B. (2012). Understanding autism: how family therapists can support parents of children with autism spectrum disorders, Family Process, 51 (2), 250-64, https://doi.org/10.1111/j.1545-5300.2012.01399.x.

Sekułowicz, M. (2013). Wypalanie się sił rodziców dzieci z niepetnosprawnościa, Wrocław: Wydawnictwo Naukowe Dolnośląskiej Szkoły Wyższej.

Shobana, M., Saravanan, C. (2014). Comparative Study on Attitudes and Psychological Problems of Mothers towards Their Children with Developmental Disability, East Asian Archives of Psychiatry, 24, 16-22.

Strelau, J., Jaworowska, A., Wrześniewski, K., Szczepaniak, P. (2005). Kwestionariusz radzenia sobie w sytuacjach stresowych CISS, Warszawa: Pracownia Testów Psychologicznych.

Wang, L., Li, D., Pan, S., Zhai, J., Xia W., Sun, C. (2021). The relationship between 2019-nCoV and psychological distress among parents of children with autism spectrum disorder, Global Health, 17, 23, https://doi.org/10.1186/s12992-021-00674-8.

Zdanowicz, K., Zasępa, E. (2017). Małżeństwo w percepcji matek dzieci z zaburzeniami ze spektrum autyzmu, Annales Universitatis Paedagogicae Cracoviensis. Studia Psychologia, 10, 147-160, https:/ / doi.org/10.24917/20845596.10.10.

\section{Netography:}

http://psych.uw.edu.pl/wpcontent/uploads/sites/98/2021/01/Raport_objawy_depresji_leku_IV_fa le.pdf 
https://ibima.org/accepted-paper/styles-of-coping-with-stress-and-social-support-for-mothers-ofchildren-with-asd-during-the-sars-cov-2-pandemic/ (b)

https://ibima.org/accepted-paper/the-material-situation-of-families-and-the-frame-of-mind-andemotions-experienced-by-children-with-asd-during-the-sars-cov-2-pandemic/ (a)

https:// www.nia.org.pl/wp-content/uploads/2020/04/FIP-Przewodnik-COVID-19-PL-002.pdf 